\title{
The Christ-figure in Popular Films
}

\author{
By Anton Karl Kozlovic
}

Fall 2005 Issue of KINEMA

\section{JESUS COVERED IN A SECULAR WRAPPER: THE CHRIST-FIGURE IN POPULAR FILMS}

POPULAR feature films ${ }^{(1)}$ should be put to work in the classroom, home or pulpit as a scholarly extra-ecclesiastical resource, and not relegated in a knee-jerk fashion to the status of visual aide, diversionary entertainment or student pacifier. In addition, religion, literature and film studies students should be sensitised to the numerous religious figurations hidden within their everyday video fare. After all, as Linda A. Mercadante (God 3) noted: "more than just media inundation, we have come to live in a media-mediated culture, where our understanding of life, reality and our own experience is filtered through video frames," unsettling as that may be to older generations.

Mercadante's claim is of course understandable given that commercial feature films were the most persuasive art form of the $20^{\text {th }}$ century, and they will continue to be so well into the $21^{\text {st }}$ century. Not only were popular films responsible for the birth of the "Age of Hollywood" (Paglia 12) and the ascendancy of moving image culture, but for "many people today, especially the young, popular culture is culture, and [so] theology, to remain true to its calling, must take such cultural expressions seriously" (Simmons 254). The literature and teaching professions have a similar obligation. Since popular films can generate powerful aesthetic, emotional and spiritual effects, they can also significantly change ones' perceptions of love, life and faith (Kozlovic Epiphanies). For example, Kathleen S. Nash enthusiastically confessed how she now reads biblical texts differently because of her exposure to the cinema:

[Take] Pulp Fiction, for example. Now, whenever I read or think about New Testament parables, I look for the motorcycle named Grace that speeds characters off into second chances and new life. To discuss the Wise Woman and the Foolish Woman of Proverbs, I invoke the demure, domestic/ated Beth [Anne Archer] and the wildly sexual Alex [Glenn Close] of Fatal Attraction. Bette Davis [playing Julie Morrison] descending the stairs in an off-the-shoulder gown [in Jezebel] is forever fused with the image of the queenly Jezebel dressed in her finest to mock Jehu from a second-story palace window, as she engineers her own death [2 Kings 9:30-37].(2) (188)

Indeed, many traces of Judaeo-Christianity can be found within the popular cinema in various genres, guises and formats, and which are not always easy to detect at first glance. For example, as Jorg Herrmann noted:

In Jurassic Park the symbol of creation is alluded to, in Titanic the book of Revelation is quoted, in Forrest Gump they pray and talk about Jesus, in The Lion King a ritual occurs which is strongly reminiscent of baptism, in Pulp Fiction one finds the book of Ezekiel together with a miracle and a conversion. (191)

This cinematic phenomenon is an exciting form of religious entertainment-cum-education, but for professional religious educators, their existence, popularity and cultural pervasiveness also incurs another serious responsibility. As Adele Reinhartz argued:

While popular movies generally convey a positive view of the Bible and its role as sacred Scripture, we as students and teachers of biblical literature should worry about those for whom popular culture is a primary vehicle of biblical knowledge. Our mission, should we choose to accept it, is to help our students to an educated reading of the text against which movies and other popular representations of the Bible may be tested. (Scripture 10)

This pedagogic task can thus be seen as the mission for religious educators in this postmodern, post-Millennial and increasing post-Christian age. After all:

Jesus' parting words were to go into all the world (Matthew 28:19). That means not only India and China, but also New York and Los Angeles. God is calling "pop culture missionaries," as 
well as people committed to praying for those working in arts and entertainment. The only requirement is love for Christ and a willingness to be real and honest with unchurched people. (Nasfell 35)

Faithful Christians also have the religious duty of scrutinising the signs of the times (Matt. 16:3), and what better way to begin than by seeking these signs upon the silver screen - the cultural focus of the social psyche, home of the collective unconscious, and frequent subject of our dreaming.

\section{Overt (Textual) Versus Covert (Subtextual) Representations}

The biblical epic genre is, of course, the most obvious manifestation of the Judaeo-Christian religion within mainstream Hollywood cinema. This is especially evident by the rash of post-1950s films such as David and Bathsheba, The Greatest Story Ever Told, King of Kings, The Ten Commandments, all of which were triggered by the success of Cecil B. DeMille's "watershed film" (Schatz 394), Samson and Delilah. Today, there is an ever-increasing body of critical literature devoted to the genre (Babington and Evans; Baugh; Campbell and Pitts; Forshey; Kinnard and Davis; Stern, Jefford and DeBona; Tatum; Walsh). Yet, however delightful this genre may be, religion-and-film (aka celluloid religion; cinematic theology; theo-film; film-faith dialogue) does not stop there. A more prolific means of spreading holy stories within the secular media is via the phenomenon of sacred subtexts (aka holy subtexts; divine infranarratives), which has been described as "anonymous religiousness" (Gallagher 151) or the pursuit of "overtly religious themes in a secular 'wrapper'" (Ellis 304). Sacred subtexts are essentially hidden religious figurations that are detectable if one has the eyes to see, the ears to hear (Ezek. 44:5), and are willing to seek them out.

They exist because storytelling narratives can have a dual nature, namely, an overt plot plus a covert storyline of varying complexity that is comparable to the metaphorical or symbolic within literature. As Bernard Dick described this relationship: "the narrative and infra-narrative (or text and subtext) are not two separate entities (there is, after all, only one film); think of them, rather, as two concentric circles, the infranarrative being within the narrative" (129). Through this narratological arrangement, secular films can engage in religious storytelling without appearing "religious," and thus potentially scare off non-believers, atheists, or the religiously wounded with unforgiving dispositions.

Yet, they are also very easy to detect, and once sensitised to the phenomenon, one cannot avoid seeing them everywhere, especially the Christ-figure - the cinematic transfiguration of Jesus Christ (Kozlovic Cinematic). As Adele Reinhartz explained regarding this Hollywood favourite:

...Jesus is not portrayed directly but is represented symbolically or at times allegorically. Christ figures can be identified either by particular actions that link them with Jesus, such as being crucified symbolically (Pleasantville, 1998), walking on water (The Truman Show, 1998) or wearing a cross (Nell, 1994; Babette's Feast, 1987). Indeed, any film that has redemption as a major theme (and this includes many, if not most, recent Hollywood movies) is liable to use some Jesus symbolism in connection with the redemptive hero figure. (Jesus 189)

Overall, the "idea of 'the Christ-figure' seeks to counter the straitjacketing of Jesus in physical correspondence to a stereotype. Instead, it seeks to show his essence revealed in action" (Coates 80). Since it is a living and vibrant genre, the popular cinema is full of Christ-figures, and they grow in number, diversity and complexity yearly (Baugh; Deacy; Kozlovic Bible, Transmogrified, Feature, Lamb, Christ-figures, Sacred; Kreitzer New, Gospel; Scully). However, much more work is needed to identify, sort and categorize them for future pedagogic deployment in the classroom, home and pulpit. Consequently, the critical religion and film literature was reviewed and integrated into the text to enhance narrative coherence (albeit with a strong reportage flavour). Using textually-based, humanist film criticism as the analytical lens (Bywater and Sobchack), the critical literature was reviewed and the popular cinema scanned to reveal three varieties of Christ-figures: (a) male Christ-figures, (b) female Christ-figures, and () science fiction Christ-figures. The following is a brief explication of each of these taxonomic categories.

\section{Male Christ-figures}

The male Christ-figure is a very common form of sacred subtext. As Stromgren and Norden pointed out:

One of the most durable of mythic structures is the story of Christ; it has been a part of our 
world for almost 2,000 years, and there is no question that its most fundamental premise-a "good" outsider interceding in the wayward affairs of others-has found its way into cinema. In addition to forming the backbone of films based specifically on the life of Christ, both traditional (King of Kings, The Greatest Story Ever Told) and updated (Jesus Christ Superstar, Godspell), this basic premise has also helped structure films that have seemingly little to do with the Christ story: a western (Shane), a domestic psychodrama (Knife in the Water), and science fiction (The Day the Earth Stood Still, Superman) to name a few. (255)

However, Christ-figures are not to be confused with Jesus-figures. As Peter Malone explained concerning the essential ontological differences between the two:

"Jesus-figure" refers to any representation of Jesus himself. "Christ-figure" describes any figure in the arts who resembles Jesus. The personal name of Jesus (in line with contemporary spirituality, thought and practice) is used for the Jesus-figure. The title "Christ" - the "Messiah," or the "Anointed One" - is used for those who are seen to reflect his mission. In cinema, writers and directors present both Jesus-figures and Christ-figures. (Jesus 59-60)

Because of their greater dramaturgical flexibility, Christ-figures can appear in the most unexpected of places: for example, in the form of the nineteen-year-old, virgin postal worker Tomek (Olaf Lubaszenko) in Krzysztof Kielowski's A Short Film About Love. This film was not set in ancient Judea with Roman soldiers trudging everywhere and the populace wearing togas in a hot, uncomfortable climate. Rather, it was set in contemporary Poland and its protagonist did not look anything like the traditional representations of Jesus Christ, however, he did echo elements of both the New Testament Jesus and the extra-canonical Jesus of Western culture.

The object of Tomek's love was the sexually promiscuous Maria Magdalena (Frazyna Szapolowska). As Lloyd Baugh described it, the film is about "the story of a love-relationship that is authentic, committed and redemptive, a love-story that is nothing less than an elaborate metaphor of the redemptive-salvific encounter of Jesus Christ and the sinner [Luke 7:36-50]" (Cinematographic 552). Given Kielowski's choice of character name, it is obvious that Maria Magdalena is metaphorically Mary Magdalene - the passionate penitent of Scripture (Matt. 27:56,61; 28:1; John 19:25). A firm link has also been made between the unnamed sinner of Luke 7:36-50 and Mary Magdalene, which is also a popular belief, even if the subject of controversy amongst biblical scholars, some of whom think this linkage is erroneous (Overman 499). Also, the fact that Tomek is secretly in love with Maria is indicative of that ancient extra-canonical tradition of Jesus and Mary Magdalene being secret lovers (Thiering chpt. 17), but obviously an idea not supported by mainstream Christianity.

Apparently, Lloyd Baugh was keen not to rile believer sensitivities and be subjected to potential accusations of blasphemy, harassment or worse for, as he claimed:

From the outset it is important to understand that in this essay we will be moving back and forth between the literal meaning of the film text and its figurative or metaphorical meaning. The primary focus of the article is on the significance of the metaphorical level of the film, that is, on the text insofar as it can be seen and interpreted as a metaphorical expression of the Christevent. The two principal protagonists exist, act, interact and have meaning within the context of a fictional story set in Warsaw in 1988; they are not to be considered Jesus and the sinner. Their correspondence to biblical characters and events and the christic significance of their rapport results from the analysis, according to a theological hermeneutic, of the metaphorical meaning of the film text. (Cinematographic 552)

One suspects that this protective comment occurred because of the good Father's past negative experiences while showing the film in public to teach moral lessons. As he had confessed a half decade earlier:

More than once, in public film-forums using A Short Film About Love, I have seen members of the audience walk out of the hall before the discussion even began. Sometimes members of the public have criticized me for including such a "perverted" film in a cycle of religious cinema. For some, even the erroneous Italian title, Do Not Desire the Wife of Another, is already too much. (Baugh Imaging, 293) 
Regrettably, such hostile public responses are a natural hazard for those engaging in the sacred subtext enterprise, and especially where sex and Jesus are involved.

Nor is the existence of Christ-figures limited geographically or nationally. In contradistinction to seeing Truman Burbank (Jim Carrey) as an Adam figure living in the paradisiacal Seahaven within The Truman Show (Drane 169; Patterson 1), Deane-Peter Baker saw him as another outstanding Christ-figure:

Here we have Truman carried towards salvation by a boat named after Jesus Christ's mother [i.e., Santa Maria]. And then we see the God-like figure of Christof [Ed Harris] pour out his wrath onto Truman through the storm he brings to bear, which he later stills with a word, and we see Truman lying spreadeagled on the boat, as if crucified, looking for all the world as if he is dead. But his apparently undefeatable human spirit resurrects him from his death-like state, and he continues doggedly on, finally reaching the boundary of the creator's control. As he explores this boundary, he appears to walk on water, until he finds a way he can exit. There can be little doubt that the creators of this movie had a strong religious theme in mind - even the name of the central character, Truman, or the 'true-man', is noticeably messianic. (105) [original emphasis]

Given the intrinsic nature of this subtextual phenomenon, it is not surprising to find that Christ-figures need not be exclusively male. Female Christ-figures are just as legitimate and theologically appropriate, if initially unsettling for the uninitiated.

\section{Female Christ-figures}

Technically speaking, since Christ-figures need only resemble or resonate with the behavioural characteristics and life events of the historical Jesus Christ, then female Christ-figures can just as easily fit this functional definition. Although not as prolific as male Christ-figures, many significant female examples abound within the popular cinema. For example:

...Catholic nun, Sister Helen Prejean [Susan Saradon] in Dead Man Walking (1995); Antonia [Willeke van Ammelrooy] of Antonia's Line (1995); Leeloo [Mila Jovovich], the female warrior who is revealed as the Supreme being in The Fifth Element (La Cinquieme Element) (1997); Ripley [Sigourney Weaver] of Alien Resurrection (1997), who uses her own corrosive blood to open a hole in a window of the spaceship, through which the destructive alien is sucked, and, in a searing portrayal of sacrifice, Bess [Emily Watson] of Breaking the Waves (1996) who gives her own body promiscuously, in the belief that she can thus 'save' her paralysed husband. (Telford $35)$

However, whether the child-like Bess is blessed or mentally disturbed is the crucial plot point, and thus the source of much academic controversy (Gudmundsottir; Heath; Mercadante Bess). In any case, her salacious behaviour is a source of deep concern for Christianity, despite any good intentions behind it. As Linda A. Mercadante confessed: "I worry that when they [students] do find a film with distinct christic allusions, they may uncritically accept images that have been used to promote or justify destructive human behavior" (Bess 1). It was a valid concern and fuel for further academic argument. Less worryingly, Peta Goldburg considered that the death row counsellor Sr. Helen Prejean in Dead Man Walking was an extremely profound female Christ-figure because:

For Poncelet [Sean Penn], she is the face of love, the face of Christ and the figure of Christ. In the final minutes of the film her journey parallels the journey of Jesus on the way to the cross. It begins in the toilet scene where she begs for strength to cope [aka the Garden of Gethsemane Matt. 26:36; Mark 14:32], she then walks with Poncelet to the place of execution [aka GolgothaMatt. 27:33; Mark 15:22; John 19:17], she participates in his suffering and his death and, like the good thief [Luke 23:32-33, 39-43], Poncelet looks to her for consolation and receives it. For him her face becomes the face of Christ. (137)

Not only was the executed Poncelet "analogous to the good thief," but he "died christically, that is, saved or "christified" by his contact with Jesus" (Baugh Imaging, 286). This christic event was also coupled with cruciform imagery when "Matthew Ponselet...is strapped onto the execution table with arms outreached, and then tipped upright and flanked by two officers [metaphorically, Roman soldiers - John 19:23] as he says 
his final words to the parents of his victims" (Reinhartz Scripture, 8).

Another contemporary female Christ-figure, but this time with a rock-star resonance is Selma (Björk), the Czech immigrant living in a 1960s USA in Dancer in the Dark. Jorg Herrmann called this film "a postmodern passion play" (196) where a "touch of feminist re-interpretation of the theology of the cross is mixed with early Protestant family theology" (196). Selma was the embodiment of maternal self-sacrifice (metaphorically, Jesus the Redeemer). She chose to pay for a life-saving operation for her sick son (humanity) who was suffering from a hereditary disease (inherited sin). She could have chosen freedom for herself by using the same money to reopen her legal case and overturn a guilty murder charge. Thus, avoiding her immanent hanging execution (crucifixion), but she did not do so (just like Jesus who did not fight back during his trial before Pontius Pilate - Matt. 27:12-14). Selma deliberately sacrificed herself for the love of her son and to secure his future (just like Jesus willingly dying on the cross to redeem humanity out of divine love for his earthly children).

While Deane-Peter Baker saw Truman Burbank (Jim Carrey) in The Truman Show as the film's Christ-figure (105), John Bowen suggested that Lauren (Natascha McElhone) was the film's true Christ-figure. She was a girl from Truman's high school days, and he still held a romantic torch for her. However, Lauren was a significant part of the media charade organised by Christof (Ed Harris), the God-figure producer-creator of the 24-hour reality TV show in which Truman is trapped. But she had a crisis of conscience, followed her heart and truthfully told Truman that his "life" was all a ruse and that he should get out, but she was quickly whisked away by Christof's behind-the-scenes handlers. As Bowen argued: "Jesus is like Lauren! Telling us more clearly than anything else about the bigger reality which is God, and on the first Good Friday ripped away from us by those who wanted to preserve the lie" (9).

More significantly, Truman heeded her words and decided to leave his hermetically sealed world. He literally reached the end of it when he hit the edge of the huge TV studio using a boat in his escape attempt. Then he bravely stepped out of the confines of the boat, the TV studio, and his media life and just "like Columbus, he's going to discover a New World" (Bowen 7). Lauren's truth had literally set Truman free, just as Jesus promised in John 8:32: "And ye shall know the truth, and the truth shall make you free." Here was the divine word subtextually preached, enacted and vindicated, with a promising sequel yet to be realised (the Second Coming).

For Peter Malone, one of the most moving female Christ-figures of contemporary European cinema was Agnes (Harriet Anderson) in Ingmar Bergman's Cries and Whispers. As he argued:

She is seriously ill and has a harrowing death scene. Her death affects her proud and selfish sisters and her maid who, like an earth mother, cradles her corpse as a dead Christ in Pieta-fashion. The minister at her burial speaks of her in Christ terms. He then goes on to explain the significance of her life:

"If it is so that you have gathered our suffering in your poor body, if it is so that you have borne it with you through death, if it is so that you meet God over there in the other land, if it is so that He turns His face towards you, if it is so that you can speak the language that this God understands, if it is so that you can, then speak to this God. If it is so, pray for us ... Pray for us who are left here on the dark, dirty earth under an empty and cruel Heaven. Lay your burden of suffering at God's feet and ask Him to pardon us. Ask him to free us at last from our anxiety, our weariness and our deep doubt. Ask Him for a meaning to our lives. Agnes, you who have suffered so unimaginably and so long, you must be worthy to plead our cause."

This is Christ-figure symbolism at its best. (Movie, 79) [original emphasis]

As strange as female Christ-figures may appear at first glance, their science fiction (SF) equivalents can sometimes stretch the limits of (in)credulity even further, but they can be just as rewarding, if not more so, to ponder.

\section{Science-Fiction Christ-figures}

Science fiction is the genre of speculation that has provided a perfect home for religious storytelling worldwide. 
After all, the scriptural Jesus Christ can be seen as a human-looking alien who came to this planet from off-world (heaven) to fulfill his divine mission (death via selfless sacrifice). He then returned (ascension) to his home (heaven) after the successful completion of his earthly mission (crucifixion) that reaped humanity an inestimable boon (the redemption of all humanity). SF Christ-figures are easily detectable vis-a-vis the regal Klaatu-Mr. Carpenter (Michael Rennie) in The Day the Earth Stood Still, the cute E.T. (voice of Pat Welsh) in E.T.: The Extra-Terrestrial, the cosmic tourist Prot (Kevin Spacey) in K-Pax, and the "chosen one" Neo (Keanu Reeves) in The Matrix. ${ }^{(3)}$ Also, the visiting man from the stars (Jeff Bridges) in Starman, the superhero Kal-El/Clark Kent/Superman (Christopher Reeve) in Superman: The Movie and the timetravelling savior James Cole (Bruce Willis) in Twelve Monkeys (Kozloff; Kozlovic Holy, Superman; McMillan; Ruppersburg). These transcendental heroes were popular transfigurations of Jesus Christ that for once were not "long on style but short on substance" (Ortiz 171). In fact, the SF cinema is replete with many weird and wonderful examples of Christ-figures, for example, the Vulcan scientist Spock, the ex-cop "Mad" Max, and the rogue planet Zyra, all of which are worthy of further explication.

\section{Spock: The Alien Messiah}

In Star Trek II: The Wrath of Khan, the character of science officer Spock (Leonard Nimoy) was constructed as an alien Messiah. This half-human, half-Vulcan Christ-figure (just like Jesus was both human and divine) voluntarily sacrificed himself (via a fatal dose of radiation) to save the crew of the starship Enterprise (microcosmically Earth) from sure death (Adamic sin), just like Jesus who gave his life as a ransom for the crew of planet Earth (Matt. 20:28; Mark 10:45). As Larry J. Kreitzer pointed out, the film contained:

...its own versions of Good Friday and a hint of the Easter Sunday to come, as well as its equivalent of the Last Supper, the symbolic meal that anticipated the impending death of Jesus...Not only is Spock's act of self-sacrifice to save the ship presented in such a way that it echoes with Christ's surrender for others on the Cross at Calvary, but the shot of Spock's coffin landing on the Genesis planet hints at the possibilities of a future resurrection...Spock's exhortation that McCoy [DeForest Kelley] should "Remember!" is reminiscent of the command issued by Jesus Christ to his disciples at the Last Supper, "Do this in remembrance of me." (recorded in Luke 22:19 and 1 Corinthians 11:24). The two stories (the narrative world of Jesus in the New Testament and the imaginative world of Star Trek) are united in that they contain an all-important call by the one who is to die (Spock in Star Trek and Christ in the New Testament) to the one(s) who are left behind (McCoy in Star Trek and the twelve Apostles in the New Testament) that they are to remember and not forget. (Suffering, 155-156)

Furthermore, as Donald E. Palumbo pointed out:

Scotty [James Doohan] pipes "Amazing Grace" as Spock's coffin is ejected into space, suggesting that Spock is like Christ, in having sacrificed himself for his fellows, and that, like Christ, he too will be reborn. McCoy [DeForest Kelly] tells Kirk [William Shatner] that Spock is "really not dead as long as we remember him." Kirk notes in his eulogy that "his death takes place in the shadow of new life" and associates it with "the sunrise on a new world"...Spock is symbolically resurrected in the final, accompanying voiceover, in which it is he, not Kirk, who speaks the well-known, standard prologue used in each Star Trek episode on television. (219)

The film producers also remembered Spock, for he was reprieved, resurrected, re-birthed, rescued, re-educated and then reintegrated into his former science officer role in Star Trek III: The Search for Spock and the rest of the ever-increasing Star Trek franchise. Indeed, scholars have explored many fruitful relationships between religion, theology and Star Trek in its TV and film forms (Ebel; Kraemer, Cassidy and Schwartz; Mitchell; Porter and McLaren; Schultes). Interestingly, Leonard Nimoy based Spock upon Michael Rennie's KlaatuMr. Carpenter, the alien Messiah from The Day the Earth Stood Still (Naha 260). This obscure fact further enhances a christic interpretation of Spock who has traditionally been conceived as one of the "unemotional patron saints of computer scientists" (Picard 280).

\section{ii. "Mad" Max: The Saviour Christ-figure}

Another famous, if unappreciated SF Christ-figure is "Mad" Max Rockatansky (Mel Gibson) from the apocalyptic Mad Max trilogy. While director George Miller argued that the cute pig Babe (voice of Christine Cavanaugh) from Babe, Pig in the City was "much closer to a Christ figure than Max" (Malone Myth, 89), 
many commentators could not avoid seeing the messianic parallels between Max and Christ. For example, John Baxter considered Max a Christ-figure simply for "taking on the sins of the whole world of which he is a part" (117). David Stratton considered "Max as almost a Christ in leather" (86) while Jessica Lindohf considered that Max's messianic expectations pervaded the entire saga because:

Max struggles with being the saviour throughout the trilogy of films. He goes through a messianic struggle of denial, temptation and acceptance. In the first film [Mad Max] he loses everything and takes refuge in the wasteland. In the second film, Road Warrior [aka Mad Max 2], his struggle stands between being the helper of the commune or minding his own business. He seeks solitude like an Old Testament prophet or hermit and lives alone in the desert [as did Jesus - Matt. 4:1-2, Luke 4:1-2]. In the final film, Thunderdome, Max finally accepts the role of saviour. (196)

Understandably, Mad Max Beyond Thunderdome contained the most detailed christomorphic patterning within the film trilogy, which director George Miller may not have been entirely aware of considering his Babe comment (Malone Myth, 89). For example, Max goes on a perilous journey through the desert after being rejected and treated like a scapegoat (the unrecognised prophet) by the controllers of Bartertown (Imperial Rome). He is rescued by the wild children of the desert (a tribe of Israel) and is introduced to the pious community of the faithful (The Waiting Ones) who are living in a green gorge called Crack in the Earth (an Eden-like oasis). Tellingly:

When the lost tribe first meets Max he asks them who they are, and the answer is:

We are the waiting ones.

Waiting for who?

Waiting for you.

Who do you think I am?

The dialogue depicts the messianic expectations of the lost tribe, and Max asks the waiting ones a similar question to that Jesus in Mark 8:29 posed to his disciples 'who do you say that I am?' (Lindohf 195-196)

Max is later suspended over a pool of water (the Jordan) and then dunked (baptised). He arises to have a meal (communion) and then hears the tribe's sacred story, "the Tell" (Gospel of hope) at an altar shaped like a TV screen (symbol of ritual space and etheric authority, which is itself an appropriate icon for the video generation). These faithful believers patiently await their expected sky-god saviour, Captain Walker (MaxJesus) who will lead them to Tomorrow-morrowland (a new Paradise) having survived an apocalyptic plane crash themselves (Armageddon). Some of the children recognise Max as the Second Coming of Walker, as indicated by the cave mural which now included a painted Max with outstretched arms resembling a crucified Christ (the iconic signature sign of the Divine). Tina Turner's theme song: "We Don't Need Another Hero" prefigured and then counterpointed Max's elevation from hero to saviour status. This concern also indirectly resonated with the many false prophets roaming around in Jesus' time, and which the Jews, Roman and Apostles had no need of (Matt. 7:15; 24:11,24; Mark 13:22; 2 Pet. 2:1; 1 John 4:1).

After the division of the children between those who will stay behind in the gorge and those who will go out into the desert (traditional religious schism), followed by an intercessory act by Max (the usual Divine prerogative), Max reluctantly accepted his christic role and acted dutifully (just like Jesus in fulfilling his earthly mission). Max (as the Good Shepherd) now became the proactive vehicle of guidance and protection of the selected tribe (the chosen; his earthly sheep) alongside Savannah Nix (Helen Buday), the physical embodiment of all the women close to the historical Jesus (e.g., the Marys). Later, Max signposted himself as the sacrificial saviour when he denied himself his own personal safety (just like Jesus who did not call down angels to save himself - John 18:36) so that the faithful children (Jesus' followers) could be lifted up on high in an airplane (spiritual elevation towards heaven). Thus, Max's selfless Jesus-like sacrifice allowed his followers (those who accepted him as Messiah) to reach their promised land, albeit, the skeletal remnants of Sydney (the new Paradise), which was waiting to be rejuvenated (akin to the duties of the post-Armageddon survivors). By liberating an elect few into a new dimension of communal harmony, Max (as Christ-figure) had set the foundations for a new world order (a post-Armageddon paradise), especially after he had destroyed a corrupt old world order to do it (the depraved Bartertown society which was a human dunghill that was literally powered by pig shit). As Jon R. Stone put it: 
In the movie's climactic battle scene, Gibson [Max] unwittingly fulfils his destiny by first destroying the evildoers and then by freeing the society from its lex taliones structure [i.e., an eye for an eye; law of retaliation], a structure in which every offense [in Bartertown] is punished either by a duel to the death or banishment to the outer desert. (71)

Subsequently, in this new world order, a new myth/"Tell"/sacred story (i.e., an Extra Testament) about Max (the deliverer) was preached by Savannah Nix in her expanded role as the new world order's priestess (sacred servant). She now actively fostered a new community mentality, "the Tell of us all" (a globalised sacred story designed to harmonise society). After his mission was complete, Max, the confirmed messianic hero-saviour was not seen again by his earthly followers (like Jesus Christ after his ascension), he only lived on in the hearts, minds and stories of his followers (just like Jesus does today among Christians). This claim was reinforced by the narrator-Feral Kid-cum-chief of the Great Northern Tribe (just like Jesus' story was told by intimate-cum-apostolic witnesses-cum-Gospel scribes).

Given all the above, it is not too surprising to find Dennis Barbour arguing that the theme of the "Mad" Max trilogy "is redemption, of both the character Max and the society he reluctantly helps" (29). Or that the trilogy can be legitimately interpreted as a postmodern recasting of Christian mythology with Max displaying personalistic traits and experiencing similar life events to the scriptural Jesus. In fact, Jesus Christ was the man that nobody knows, but he had multiple designations. For example: mad (John 7:20), insignificant tradesman (Matt. 13:54-57), the good shepherd (Matt. 25:32), the rejected one (Luke 4:29), the wanderer (Matt. 8:20), friend of sinners (Matt.11:19), knowledgeable (John 15:14-15), divine warrior (Luke 4:14), liberator (Gal. 1:4), deliverer (Rom. 7:24-25), teacher/Rabbi (John 1:38). (See Ryken, Wilhoit and Longman III). These Jesus descriptions also describe Max throughout the trilogy. In short, "Mad" Max was a not-so-mad Christ-figure.

\section{iii. Zyra: The Planetary Christ-figure}

More amazingly, one need not even be human or alive to qualify as a valid Christ-figure. For example, Glenn Erickson argued that the rogue moon Zyra from the 1950s disaster classic When Worlds Collide was a subtextual Jesus. As he argued:

Devout producer [George] Pal retained the book's Christ metaphor that made the stellar apocalypse into a thinly disguised Second Coming. Two heavenly bodies, the planet Bronson Alpha (or Bellus in the film) and its smaller satellite Bronson Beta (Zyra) will intersect Earth's orbit in only eight months. Bellus, representing the Old Testament Jehovah, will smash the Earth to pulp, killing every living soul. No simple flood this time folks ...but Earth has a second chance, of sorts. A few weeks before the arrival of Bellus, its moon Zyra, representing Jesus Christ, will pass close by our planet, causing massive earthquakes, tidal waves and other assorted havoc. Only the Chosen Few technocrats who believe in science and are daring enough to build Space Arks to fly to Zyra will be saved. (2)

Although such a christic interpretation is technically legitimate, this SF gem is better understood as a film about "a $20^{\text {th }}$ century Noah's Ark" (Willis 307) with strong Edenic resonances. Of course, finding the limits of (in)credulity regarding Christ-figures is always going to be the question in this scholarly enterprise, but well worth the academic effort for the christological insights that can be gleaned.

\section{Conclusion}

Christ-figures (and other subtextual religious figurations) are a legitimate pop culture phenomenon whose artistic permutations are delightful and increasingly understandable in this age of the moving image. Regrettably, the pedagogic application of this pervasive phenomenon is currently under-valued and under-utilised within formal educational settings, whether the classroom, home or pulpit. Yet, its future utility for secular film studies and a postmodern religious education looks very promising, especially as a means of teaching and honing students' video exegesis skills.

More importantly, it is a cheap, dramatically engaging and readily accessible means of reintroducing the foundational myths of our Western society back to ourselves, but this time in media garb more easily recognised by the proverbial children of the media. Particularly considering the decline of Scripture Studies in schools, the lack of Bible reading amongst the public, and the anti-religion biases of many secular institutions. 
It is argued that a closer, more sympathetic examination of this exciting field will certainly yield many more insights and delights unappreciated to date, and hopefully make the topic of religion be something that is fun and to be enjoyed rather than endured. Further research into the emerging and exciting interdisciplinary field of religion-and-film is warranted, recommended and certainly long overdue.

\section{Notes}

1. Although there are real ontological differences between "film," "cinema," "movie," "video," "TV movie," "CD," "DVD" etc., they will be treated herein as essentially interchangeable.

2. The Authorized King James Version of the Bible (KJV aka AV) will be used throughout, unless quoting other translations.

3. The Matrix can also be used to explore concepts of Buddhism and Eastern mysticism (Ford; Ho), in addition to Christianity via the Christ-figure phenomenon. However, as Jeffrey B. Ho warned: "Trying to transform a filmmaker's Jesus-like character into a Buddha in a typical US college classroom can be quite challenging" (208).

\section{References}

Babington, Bruce, and Peter W. Evans. Biblical Epics: Sacred Narrative in the Hollywood Cinema. Manchester: Manchester UP, 1993.

Baker, Deane-Peter. "Transcendental Arguments: The Truman Show and Original Sin." Journal of Theology for Southern Africa 113 (2002): 97-108.

Barbour, Dennis H. "Heroism and Redemption in the Mad Max trilogy." Journal of Popular Film ES Television 27.3 (1999): 28-34.

Baugh, Lloyd. Imaging the Divine: Jesus and Christ-figures in Film. Kansas City: Sheed and Ward, 1997.

. "Cinematographic Variations on the Christ-event: Three Films by Krzysztof Kielowski. Part One: A Short Film About Love." Gregorianum 84.3 (2003): 551-583.

Baxter, John. "Max's Road: Some Structures in the Films Mad Max and Mad Max 2. Contrary Modes: Proceedings of the World Science Fiction Conference, Melbourne, Australia, 1985. Eds. Jenny Blackford, Russell Blackford, Lucy Sussex and Norman Talbot. Melbourne: Ebony Books/Department of English, U of Newcastle, 1985. 105-121.

Bowen, John. The Gospel According to The Truman Show. , (1999): 1-9.

Bywater, Tim, and Thomas Sobchack. An Introduction to Film Criticism: Major Critical Approaches to Narrative Film. New York: Longman, 1989.

Campbell, Robert H., and Michael R. Pitts. The Bible on Film: A Checklist, 1897-1980. Metuchen, NJ: The Scarecrow P, 1981.

Coates, Paul. Cinema, Religion and the Romantic Legacy. Aldershot: Ashgate, 2003.

Deacy, Christopher. Screen Christologies: Redemption and the Medium of Film. Cardiff: U of Wales P, 2001.

Dick, Bernard F. Anatomy of Film, 3rd ed. New York: St. Martin's P, 1998.

Drane, John. Cultural Change and Biblical Faith: The Future of the Church. Biblical and Missiological Essays for the New Century. Carlisle, UK: Paternoster, 2000.

Ebel, Henry. "The New Theology: Star Trek, Star Wars, Close Encounters, and the Crisis of Pseudorationality." The Journal of Psychohistory: A Quarterly Journal of Childhood and Psychohistory 5.4 (1978): 487-498. 
Ellis, Robert. "Movies and Meaning." The Expository Times 112.9 (2001): 304-308.

Erickson, Glenn. DVD Savant Review: When Worlds Collide. , (2001): 1-6.

Ford, James L. "Buddhism, Christianity, and The Matrix: The Dialectic of Myth-making in Contemporary Cinema." The Journal of Religion and Film 4.2 (2000): 1-10. [http://www.unomaha.edu/ wwwjrf/thematrix.htm].

Forshey, Gerald E. American Religious and Biblical Spectaculars. Westport, CT: Praeger, 1992.

Gallagher, Michael P. "Theology, Discernment and Cinema." New Image of Religious Film. Ed. John R. May. Kansas City: Sheed \& Ward, 1997. 151-60.

Goldburg, Peta. "Jesus Movies: What You See and What You Get." Echo and Silence: Contemporary Issues for Australian Religious Education. Ed. Maurice Ryan. Katoomba, NSW: Social Science P, 2001. 126-138.

Gudmundsottir, Arnfridur. "Female Christ-figures in Films: A Feminist Critical Analysis of Breaking the Waves and Dead Man Walking." Studia Theologica 56.1 (2002): 27-43.

Heath, Stephen. "God, Faith and Film: Breaking the Waves." Literature $\mathscr{E}$ Theology 12.1 (1998): 93-107.

Herrmann, Jorg. "From Popular to Arthouse: An Analysis of Love and Nature as Religious Motifs in Recent Cinema." Mediating Religion: Conversations in Media, Religion and Culture. Eds. Jolyon Mitchell and Sophia Marriage. London: T \& T Clark, 2003. 189-199.

Ho, Jeffrey B. "The Matrix: Using American Popular Film to Teach Concepts of Eastern Mysticism in the College Classroom." Reversing the Lens: Ethnicity, Race, Gender, and Sexuality Through Film. Eds. Jun Xing and Lane R. Hirabayashi. Boulder, CO: UP of Colorado, 2003. 197-211.

Kinnard, Roy, and Tim Davis. Divine Images: A History of Jesus on the Screen. New York, NY: Citadel P, 1992.

Kozloff, Sarah. R. "Superman as Saviour: Christian Allegory in the Superman Movies." Journal of Popular Film and Television 9.2 (1981): 78-82.

Kozlovic, Anton K. "The Bible is Alive and Well and Living in Popular Films: A Survey of Some Western Cinematic Transfigurations of Holy Writ." Australian Religion Studies Review 13.1 (2000a): 56-71.

. "Cinematic Epiphanies: Popular Films as Sites for Reel Devotion and Psycho-spiritual Encounters."

Religious Education Journal of Australia 16.1 (2000b): 20-25.

. "The Transmogrified Bible: A Survey of Some Popular Western Cinematic Transfigurations of Biblical Characters." Religious Education Journal of Australia 17.1 (2001a): 7-13.

. "From Holy Aliens to Cyborg Saviours: Biblical Subtexts in Four Science Fiction Films." The Journal of Religion and Film 5.2 (2001b): 1-13.[http://www.unomaha.edu/ wwwjrf/cyborg.htm].

"Superman as Christ-Figure: The American Pop Culture Movie Messiah." Journal of Religion and Film 6.1 (2002a): 1-25.[http://www.unomaha.edu/ wwwjrf/superman.htm].

"Feature Films and Sacred Subtexts: Popular Visual Piety as Applied Religious Education." Religious Education Journal of Australia 18.2 (2002b): 3-10.

"Have Lamb Will Martyr: Samson as a Rustic Christ-figure in Cecil B. DeMille's Samson and Delilah (1949)." Reconstruction: Studies in Contemporary Culture 3.1 (2003a): 1-23. [http://www.reconstruction.ws/031/kozlovic.htm].

. "Christ-figures and Other Hidden Biblical References in Popular Films: The 20th Century Biblia Pauperum." Journal of Religious Education 51.1 (2003b): 57-64.

"Sacred Subtexts and Popular Film: A Brief Survey of Four Categories of Hidden Religious Figurations." Journal of Contemporary Religion 18.3 (2003c): 317-334.

$26-30$.

. "The Cinematic Christ-figure." The Furrow: A Journal for the Contemporary Church 55.1 (2004): 
Kraemer, Ross S., William Cassidy, and Susan L. Schwartz. Religions of Star Trek. Boulder, CO: Westview P, 2001.

Kreitzer, Larry J. The New Testament in Fiction and Film: On Reversing the Hermeneutical Flow. Sheffield: JSOT P, 1993.

. "Suffering, Sacrifice and Redemption: Biblical Imagery in Star Trek." Star Trek and Sacred Ground: Explorations of Star Trek, Religion, and American Culture. Eds. Jennifer E. Porter and Darcee L. McLaren. Albany: State U of New York P, 1999. 139-163.

. Gospel Images in Fiction and Film: On Reversing the Hermeneutical Flow. London: Sheffield Academic P/Continuum, 2002.

Lindohf, Jessica. "The Ethos of Modern Apocalyptic Stories: The Use of Judaeo-Christian Narrative in Popular Film." Virtue Ethics and Sociology: Issues of Modernity and Religion. Eds. Kieran Flanagan and Peter C. Jupp. New York: Palgrave, 2001. 186-201.

Malone, Peter. Movie Christs and Antichrists. Eastwood, NSW: Parish Ministry Publications, 1988.

"Jesus on Our Screens." New Image of Religious Film. Ed. John R. May. Kansas City: Sheed \& Ward, 1997. 57-71.

. Myth $\&$ Meaning: Australian Film Directors in their Own Words. Sydney: Currency P, 2001.

McMillan, Barry. "24 Frames... - Film Notes." The Furrow: A Journal for the Contemporary Church 53.6 (2002): 360-362.

Mercadante, Linda. "Bess the Christ Figure?: Theological interpretations of Breaking the Waves." The Journal of Religion and Film 5.1 (2001a): 1-6.[http://cid.unomaha.edu/ wwwjrf/bessthe.htm.]

"The God Behind the Screen: Pleasantville \& The Truman Show." The Journal of Religion and Film 5.2 (2001b): 1-12.[http://www.unomaha.edu/ wwwjrf/truman.htm].

Mitchell, Jolyon. "Star Trek and Theology." The Month: A Review of Christian Thought and World Affairs 31.5 (1998): 175-179.

Naha, Ed. "The Inner Search for Spock: An Interview with Leonard Nimoy." Omni's Screen Flights/Screen Fantasies: The Future According to Science Fiction Cinema. Ed. Danny Peary. Garden City, NY: Doubleday, 1984. 260-267.

Nasfell, Andrea. "Learning from the Master Story Teller: Engaging the Pop Culture." Good News: A Magazine for United Methodist Renewal 33.4 (2000): 35.

Nash, Kathleen S. "Toto, We're Not in Kansas Anymore": From Historical Criticism to Film Theory." Semeia: An Experimental Journal for Biblical Criticism 74 (1996): 183-188.

Ortiz, Gaye. "Theology and the 'Silver Screen." The Month: A Review of Christian Thought and World Affairs 31.5 (1998): 171-174.

Overman, J. Andrew. "Mary Magdalene." The Oxford Companion to the Bible. Eds. Bruce M. Metzger and Michael D. Coogan. New York: Oxford UP, 1993. 499.

Paglia, Camille. Vamps \& Tramps: New Essays. New York: Vintage Books, 1994.

Palumbo, Donald E. "The Underground Journey and the Death and Resurrection Theme in Recent Science Fiction Films." The Fantastic in World Literature and the Arts. Selected Essays from the Fifth International Conference on the Fantastic in the Arts. Ed. Donald E. Morse. New York: Greenwood P, 1987. 211-227, 239 .

Patterson, Jimmy. Is 'E.T.' a Retelling of the Christ Story? , (1999): 1-2.

Picard, Rosalind W. "Does HAL Cry Digital Tears? Emotion and Computers." HAL's Legacy: 2001's Computer as Dream and Reality. Ed. David G. Stork. Cambridge, MA: MIT P, 1997. 279-303. 
Porter, Jennifer E., and Darcee L. McLaren, eds. Star Trek and Sacred Ground: Explorations of Star Trek, Religion, and American Culture. Albany: State U of New York P, 1999.

Reinhartz, Adele. "Scripture on the Silver Screen." The Journal of Religion and Film 3.1 (1999): 1-10. [http://cid.unomaha.edu/ wwwjrf/scripture.htm].

. "Jesus on the Silver Screen." Revelation: Representations of Christ in Photography. Ed. Nissan N. Perez. London: Merrell/The Israel Museum, Jerusalem, 2003. 186-89.

Ruppersburg, Hugh. "The Alien Messiah in Recent Science Fiction Films." Journal of Popular Film 83 Television 14.4 (1987): 159-166.

Ryken, Leland, James C. Wilhoit, and Tremper Longman III, eds. Dictionary of Biblical Imagery. Downers Grove, IL: InterVarsity P, 1998.

Schatz, Thomas. History of the American Cinema. 6. Boom and Bust: The American Cinema in the 1940s. New York: Simon \& Schuster Macmillan, 1997

Schultes, John S. "Any Gods Out There? Perceptions of Religion from Star Wars and Star Trek." The Journal of Religion and Film 7.2 (2003): 1-22.[http://www.unomaha.edu/ wwwjrf/vol7no2/Schultesanygods.htm].

Scully, Michael. The Message of Film 5: Jesus in Modern Media. Milwaukee, WI: Hi-Time Publishing, 1997.

Simmons, Ernest L. "Theology of the Cross and Popular Culture." Word 83 World 23.3 (2003): 253-262.

Stern, Richard C., Clayton N. Jefford and Guerric DeBona. Savior on the Silver Screen. New York: Paulist P, 1999 .

Stone, Jon R. "'Apocalyptic" Themes on the Silver Screen." God in the Details: American Religion in Popular Culture. Eds. Eric M. Mazur and Kate McCarthy. New York: Routledge, 2001. 65-82.

Stratton, David. The Avocado Plantation: Boom and Bust in the Australian Film Industry. Sydney: Macmillan, 1990.

Stromgren, Richard L., and Martin F. Norden. Movies: A Language in Light. Englewood Cliffs, NJ: Prentice-Hall, 1984.

Tatum, W. Barnes. Jesus at the Movies: A Guide to the First Hundred Years. Santa Rosa, CA: Polebridge P, 1997.

Telford, William R. "Religion, the Bible and Theology in Recent Films (1993-1999)." Epworth Review 4 (2000): 31-40.

Thiering, Barbara. Jesus the Man: A New Interpretation from the Dead Sea Scrolls. Sydney: Bantam Books, 1993.

Walsh, Richard. Reading the Gospels in the Dark: Portrayals of Jesus in Film. Harrisburg: Trinity Press International, 2003.

Willis, Donald C. Horror and Science Fiction Films III. Metuchen, NJ: The Scarecrow P, 1984.

FILMOGRAPHY Alien Resurrection (1997, dir. Jean-Pierre Jeunet)

Antonia's Line (1995, dir. Marleen Gorris)

Babe, Pig in the City (1998, dir. George Miller)

Babette's Feast (aka Babette's Gastebud, 1987, dir. Gabriel Axel)

Breaking the Waves (1996, dir. Lars von Trier)

Cries and Whispers (aka Viskningar Och Rop, 1972, dir. Ingmar Bergman)

Dancer in the Dark (2000, dir. Lars von Trier)

David and Bathsheba (1951, dir. Henry King) 
The Day the Earth Stood Still (1951, dir. Robert Wise)

Dead Man Walking (1995, dir. Tim Robbins)

E.T.: The Extra-Terrestrial (1982, dir. Steven Spielberg)

Fatal Attraction (1987, dir. Adrian Lyne)

The Fifth Element (Le cinquième élément, 1997, dir. Luc Besson)

Forrest Gump (1994, dir. Robert Zemeckis)

Godspell (1973, dir. David Greene)

The Greatest Story Ever Told (1965, dir. George Stevens)

Jesus Christ, Superstar (1973, dir. Norman Jewison)

Jezebel (1938, dir. William Wyler)

Jurassic Park (1993, dir. Steven Spielberg)

King of Kings (1961, dir. Nicholas Ray)

Knife in the Water (1962, dir. Roman Polanski)

K-Pax (2001, dir. Iain Softley)

The Lion King (1994, dir. Roger Allers \& Rob Minkoff)

Mad Max (1979, dir. George Miller)

Mad Max Beyond Thunderdome (1985, dir. George Miller \& George Ogilvie)

The Matrix (1999, dir. Andy \& Larry Wachowski)

Nell (1994, dir. Michael Apted)

Pleasantville (1998, dir. Gary Ross)

Pulp Fiction (1994, dir. Quentin Tarantino)

The Road Warrior (aka Mad Max 2, 1981, dir. George Miller)

Samson and Delilah (1949, dir. Cecil B. DeMille)

Shane (1953, dir. George Stevens)

A Short Film About Love (aka Do Not Desire the Wife of Another; aka Decalogue Six, 1988, dir. Krzysztof Kieslowski)

Starman (1984, dir. John Carpenter)

Star Trek II: The Wrath of Khan (1982, dir. Nicholas Meyer)

Star Trek III: The Search for Spock (1984, dir. Leonard Nimoy)

Superman: The Movie (aka Superman) 1978, dir. Richard Donner)

The Ten Commandments (1956, dir. Cecil B. DeMille)

Titanic (1997, dir. James Cameron)

The Truman Show (1998, dir. Peter Weir)

Twelve Monkeys (1995, dir. Terry Gilliam)

When Worlds Collide (1951, dir. Rudolph Mate) 


\section{Author Information}

Anton Karl KOZLOVIC (PhD Flinders) researches in the Screen Studies department, School of Humanities at Flinders University (Adelaide, Australia). His interests include religion-and-film, computer films, and the biblical cinema of Cecil B. DeMille. He has published in journals including Australian Religion Studies Review, Belphegor: Popular Literature and Media Culture, The Film Journal, Journal of Contemporary Religion, The Journal of Religion and Film. 